\title{
Phytoprotection
}

\section{Attract and kill, an effective technique to manage apple maggot, Rhagoletis pomonella [Diptera : Tephritidae] in high density Quebec apple orchards Attirer et tuer, une stratégie de lutte pour réprimer la mouche de la pomme, Rhagoletis pomonella [Diptera : Tephritidae], dans les pommeraies de hautes densités au Québec}

\author{
N.J. Bostanian et G. Racette
}

Volume 82, numéro 1, 2001

URI : https://id.erudit.org/iderudit/706212ar

DOI : https://doi.org/10.7202/706212ar

Aller au sommaire du numéro

Éditeur(s)

Société de protection des plantes du Québec (SPPQ)I

ISSN

0031-9511 (imprimé)

1710-1603 (numérique)

Découvrir la revue

Citer cet article

Bostanian, N. \& Racette, G. (2001). Attract and kill, an effective technique to manage apple maggot, Rhagoletis pomonella [Diptera : Tephritidae] in high density Quebec apple orchards. Phytoprotection, 82(1), 25-34.

https://doi.org/10.7202/706212ar
Résumé de l'article

Le piégeage de la mouche de la pomme (Rhagoletis pomonella) en périphérie des vergers de pommiers s'avère une méthode efficace de répression sous certaines conditions. Pour les cultivars McIntosh, Liberty, Royal Gala et Jonagold, de 98,5 à $100 \%$ des fruits récoltés étaient exempts de piqûre. Le piège consiste en un panneau jaune $(28 \mathrm{~cm} \times 21,5 \mathrm{~cm})$ inséré entre deux demi-sphères rouges $(9 \mathrm{~cm}$ de diam). Ce piège est pulvérisé avec de la cyperméthrine à 12,5 ou $6,3 \%$ ou de la deltaméthrine à 1,7 ou $1,3 \%$, dans une solution de kérosène inodore. Les pièges, appâtés avec un sachet d'hexanoate de butyle, sont suspendus à une branche de pommier, en périphérie des vergers, à une hauteur de 1,20-1,70 m au-dessus du sol. Le nombre de pièges par parcelle varie selon la longueur des rangs latéraux exposés à des sites abritant des mouches de la pomme. À proximité des boisés, site d'entrée de la mouche de la pomme dans les vergers, les pièges sont installés à tous les 2-3 m d'intervalle $\left(0,3-0,5\right.$ piège $\left.\mathrm{m}^{-1}\right)$ sur les rangs de bordure. Un piège est également installé au début et à la fin de chacun des rangs. La distance entre les rangs varie de $4-5,5 \mathrm{~m}\left(0,18-0,25\right.$ piège $\left.\mathrm{m}^{-1}\right)$. Pour les secteurs adjacents à une prairie ou une section pulvérisée chimiquement, les pièges sont installés à tous les 2-6 $\mathrm{m}$ d'intervalle $\left(0,17-0,5\right.$ piège $\left.\mathrm{m}^{-1}\right)$ sur le rang et à tous les $4-12 \mathrm{~m}$ d'intervalle $\left(0,08-0,25\right.$ piège $\left.\mathrm{m}^{-1}\right)$ aux extrémités des rangs. Afin d'obtenir une répression satisfaisantede la mouche de la pomme pour les cultivars McIntosh, Liberty, Gala et Jonagold, il ne doit pas y avoir plus de 13 captures sur l'ensemble des quatre pièges collants en périphérie de la parcelle, ce qui correspond à 1,6 fois le nombre de captures du seuil d'intervention. 


\title{
Attract and kill, an effective technique to manage apple maggot, Rhagoletis pomonella [Diptera : Tephritidae] in high density Quebec apple orchards
}

\author{
Noubar J. Bostanian and Gaétan Racette ${ }^{1}$
}

Received 2000-11-20; accepted 2001-04-27

PHYTOPROTECTION 82 : 25-34

\begin{abstract}
"Attract and kill" is an effective technique to control apple maggot (Rhagoletis pomonella) in apple orchards. It provided 98.5 to $100 \%$ clean fruit at harvest in Mclntosh, Liberty, Royal Gala and Jonagold cvs. The traps consisted of yellow boards $(28 \mathrm{~cm} \times 21.5 \mathrm{~cm})$ sandwiched between the two halves of red spheres $(9 \mathrm{~cm}$ diam). They were sprayed with 12.5 and $6.3 \%$ cypermethrin or 1.3 and $1.7 \%$ deltamethrin in de-odorized kerosene, loaded with butyl hexanoate in semi-permeable sachets. The traps were hung on branches 1.20-1.70 $\mathrm{m}$ above the ground. They were placed on the periphery of the plot and positioned so as to be visible from outside the tree canopy. The number of traps per plot was a function of the length of the plot opposite a possible entry site of apple maggot. In columns opposite a forest, entry site of apple maggot into the plot, the traps in a column were at 2-3 m intervals $\left(0.3-0.5\right.$ traps $\left.\mathrm{m}^{-1}\right)$. A trap was also placed on every tree of the first and last row of a column. The columns were 4-5.5 m apart (0.18-0.25 traps $\mathrm{m}^{-1}$ ). Opposite to prairie grass or a chemically treated plot the traps were at 2-6 m intervals $\left(0.17-0.5\right.$ traps $\left.\mathrm{m}^{-1}\right)$ in a column. On the row, the distance between adjacent traps was 4 to $12 \mathrm{~m}\left(0.08-0.25\right.$ traps $\left.\mathrm{m}^{-1}\right)$. To achieve commercially acceptable apple maggot control in cvs. Mclntosh, Liberty, Gala and Jonagold apples with "attract and kill" technique, the activity of the pest should not exceed 13 flies per four traps placed on the periphery of the plot, in other words, 1.6 times the action threshold for the apple maggot in Quebec apple orchards.
\end{abstract}

[Attirer et tuer, une stratégie de lutte pour réprimer la mouche de la pomme, Rhagoletis pomonella [Diptera : Tephritidae], dans les pommeraies de hautes densités au Québec]

Le piégeage de la mouche de la pomme (Rhagoletis pomonella) en périphérie des vergers de pommiers s'avère une méthode efficace de répression sous certaines conditions. Pour les cultivars Mclntosh, Liberty, Royal Gala et Jonagold, de 98,5 à $100 \%$ des fruits récoltés étaient exempts de piqûre. Le piège consiste en un panneau jaune $(28 \mathrm{~cm} \times 21,5 \mathrm{~cm})$ inséré entre deux demi-sphères rouges $(9 \mathrm{~cm}$ de diam). Ce piège est pulvérisé avec de la cyperméthrine à 12,5 ou $6,3 \%$ ou de la deltaméthrine à 1,7 ou $1,3 \%$, dans une solution de kérosène inodore. Les pièges, appâtés avec un sachet

1. Horticultural Research and Development Centre, Agriculture and Agri-Food Canada, 430 Gouin Blvd., Saint-Jean-sur-Richelieu, Quebec, Canada J3B 3E6; e-mail : bostaniannj@em.agr.ca 
d'hexanoate de butyle, sont suspendus à une branche de pommier, en périphérie des vergers, à une hauteur de 1,20-1,70 $\mathrm{m}$ au-dessus du sol. Le nombre de pièges par parcelle varie selon la longueur des rangs latéraux exposés à des sites abritant des mouches de la pomme. À proximité des boisés, site d'entrée de la mouche de la pomme dans les vergers, les pièges

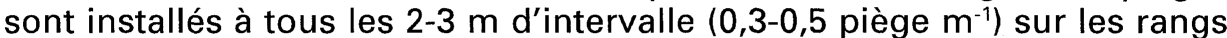
de bordure. Un piège est également installé au début et à la fin de chacun des rangs. La distance entre les rangs varie de 4-5,5 $\mathrm{m}\left(0,18-0,25\right.$ piège $\left.\mathrm{m}^{-1}\right)$. Pour les secteurs adjacents à une prairie ou une section pulvérisée chimiquement, les pièges sont installés à tous les 2-6 m d'intervalle $(0,17$ 0,5 piège $\left.\mathrm{m}^{-1}\right)$ sur le rang et à tous les $4-12 \mathrm{~m}$ d'intervalle $(0,08-0,25$ piège $\mathrm{m}^{-1}$ ) aux extrémités des rangs. Afin d'obtenir une répression satisfaisante de la mouche de la pomme pour les cultivars Mclntosh, Liberty, Gala et Jonagold, il ne doit pas y avoir plus de 13 captures sur l'ensemble des quatre pièges collants en périphérie de la parcelle, ce qui correspond à 1,6 fois le nombre de captures du seuil d'intervention.

\section{INTRODUCTION}

The apple maggot, Rhagoletis pomonella (Walsh) [Diptera : Tephritidae], is a key pest of apples in eastern Canada and the United States. It is a native insect of North America. Hawthorn (Crataegus sp.) is its natural host. However, with the introduction and commercial production of apples in North America, it has since attacked that fruit. In Canada, abandoned orchards and hawthorn trees support large populations of $R$. pomonella from Ontario to Nova Scotia. In a non-treated apple orchard, a 10-yr study showed that this pest caused on average $16.9 \%$ crop loss annually in Quebec (Vincent and Bostanian 1988). Growers, monitoring adult activity with red spheres, apply on average 1.1 insecticidal treatments per season in Quebec (Bostanian et al. 1984) and 2.2 to 3.1 treatments in Massachusetts (Prokopy et al. 1990). Meanwhile, in southern Ontario, three to four insecticidal treatments are applied when this pest and Cydia pomonella (L.) [Lepidoptera : Tortricidae] are reproductively active (Trimble and Vickers 2000).

Apple maggot adults immigrate into commercial orchards annually searching for food and oviposition sites. They are attracted to the honeydew of aphids and the odors emitted by ripening apples. Newly emerged flies are sexually immature and feed on honeydew for 7-10 d before they mate and start to oviposit. Prokopy (1968) suggested that immature flies are attracted to yellow panels because these panels mimic apple foliage. In contrast, sexually mature flies are attracted to developing fruit, the preferred site for mating and oviposition. Consequently, mature flies are attracted to red spheres that mimic a maturing apple (Prokopy 1968). To detect the presence of apple maggot, Kring (1970) developed an efficient trap that consisted of a yellow panel placed in between the two halves of a red sphere.

A better understanding of the behavior of apple maggot in orchards along with recent developments in traps and chemical attractants, has led to the development of the following management techniques: (a) border sprays; (b) perimeter trapping (also called trappingout); and (c) "attract and kill". These techniques attempt to reduce postbloom insecticide use in orchards, as such treatments may have adverse effects on non-target arthropods (Bostanian et al. 1984).

For timing border sprays, the activity of apple maggot is monitored around the periphery of a block of apple trees. When the action threshold is reached, an insecticide treatment is applied to a 50-m wide strip around the outer margin of a block. With this technique, Trimble and Vickers (2000) managed adults and larvae of codling moth $\mathrm{CCy}$ dia pomonella and apple maggot adults throughout the season in Ontario. 
For perimeter trapping, traps are used instead of insecticide applications and the traps are placed on the periphery of an orchard. Consequently, a high proportion of invading apple maggot are intercepted before they enter the interior of the block. In Massachusetts, Prokopy (1975) showed that unbaited red sticky spheres, deployed at a density of about one per 100 apple fruit, substantially reduced apple maggot infestations in well-pruned, standard apple trees. The discovery of apple volatiles (Fein et al. 1982) and a little later of synthetic volatiles (Reissig et al. 1985) that attracted adult flies were adopted in perimeter trapping. This was because the synthetic volatiles improved the technique and fewer sticky traps had to be used (Bostanian et al. 1999; Mason et al. 1994; Prokopy et al. 1990). More recently, the sticky material was replaced with an insecticide (Duan and Prokopy 1995a, 1995b). However, these insecticide treated traps had to be re-treated at least once with the insecticide and with sucrose, after every rainfall. This would be expensive and impractical in Quebec because of the high frequency of rainfall. Never- theless, the technique was an example of "attract and kill", where the pest was attracted by a synthetic food lure towards a pesticide treated surface and killed following contact.

In this study, we report the results of the "attract and kill" technique evaluated in Quebec apple orchards from 1994 to 1999. Our strategy was to use a synthetic attractant to attract adult apple maggot to traps that had been treated only once with a persistent insecticide before the beginning of fly abundance, and remained toxic to apple maggot adults for the entire season irrespective of weather conditions.

\section{MATERIALS AND METHODS}

Traps similar to the one developed by Kring (1970) were used. The traps were yellow panels $(28 \mathrm{~cm} \times 21.5 \mathrm{~cm})$ sandwiched between the two halves of plastic red spheres $(9 \mathrm{~cm}$ diam) (see insert, Fig. 1). The traps were loaded with butyl hexanoate (synthetic attractant) enveloped in semi-permeable sachets (Consep Membranes Inc., Bend, Ore-

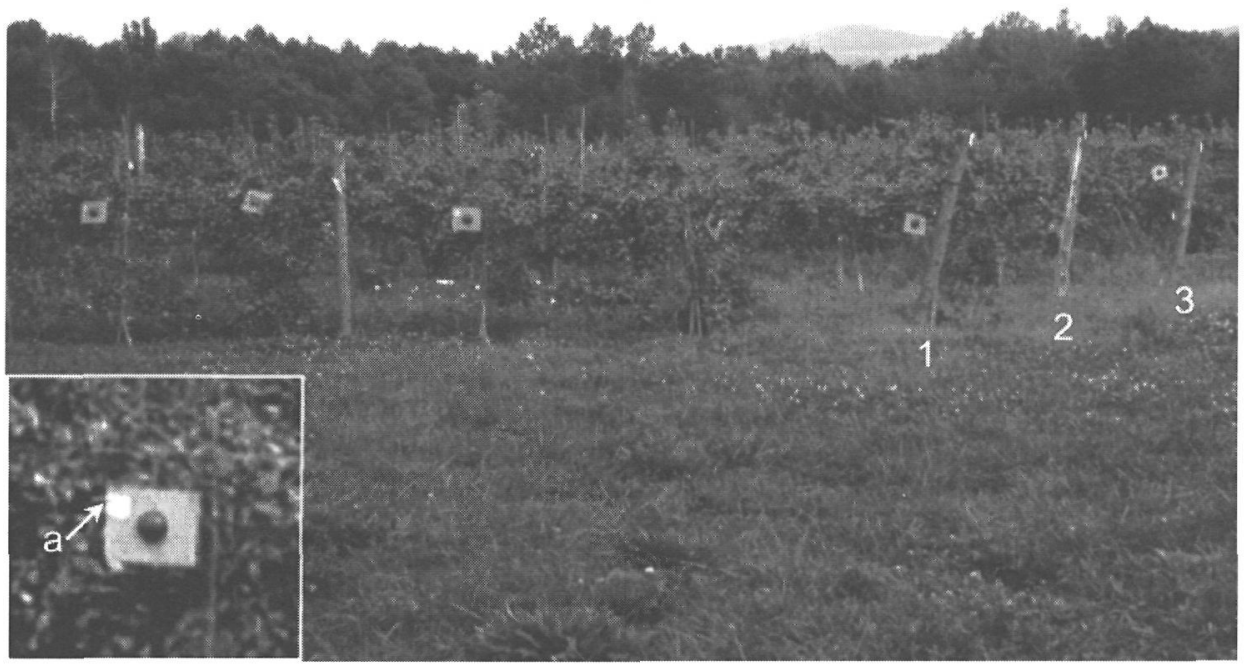

Fig. 1. Placement of "attract and kill" traps in an experimental plot. Note the columns $1,2,3$, and the traps on every tree in column 1 . The insert shows a sachet (a) containing the attractant attached on the left hand corner of the trap. 
gon USA). Each trap was treated with cypermethrin or deltamethrin before a sachet containing the attractant was stapled on its right or left hand corner (see insert Fig.1). The traps were hung on branches 1.20-1.70 $\mathrm{m}$ above the ground and positioned so as to be totally visible from outside the tree canopy (Fig. 1). Apple maggot activity was monitored by placing four similar traps, at the four corners of the plot and another four traps near the centre of the plot. These traps were coated with a thin coat of adhesive (i.e., Tangletrap ${ }^{\mathrm{TM}}$, Tanglefoot Co., Grand Rapids, Michigan) instead of the insecticide.

Maximum apple maggot activity was determined by the sum of fly catches on the four peripheral traps when the flies were at maximum activity at any particular date and dividing the sum by eight (the nominal action threshold for maggot activity). A regression analysis was performed on the data relating maximum activity of flies to percent uninjured fruit at harvest. Check plots were treated with an insecticide when the recommended action threshold of eight flies (cumulative) per four traps was attained. The concentrations of the insecticides used on the "attract and kill" technique traps as well as the reference check plots are reported in Table 1 .

At harvest, percent uninjured fruit was estimated from 1000 to 1500 apples that had been picked at random and dissected to establish injury caused by maggot.

An exploratory study was carried out at Frelighsburg Quebec in a cv. Empire plot (0.6 ha) in 1994. The south and east sides of the plot were surrounded

Table 1. Apple maggot Rhagoletis pomonella (Walsh) management in Quebec apple orchards 1995-1999

\begin{tabular}{|c|c|c|c|c|c|c|c|c|}
\hline \multirow[b]{2}{*}{ Cultivar } & \multirow[b]{2}{*}{$\begin{array}{c}\text { Trial } \\
\text { designation }\end{array}$} & \multirow[b]{2}{*}{ Year } & \multicolumn{2}{|c|}{ Insecticides used } & \multicolumn{2}{|c|}{$\begin{array}{l}\text { Max. fly activity } \\
\text { in the season }\end{array}$} & \multicolumn{2}{|c|}{ Uninjured fruit $(\%)$} \\
\hline & & & Attract \& kill & $\begin{array}{c}\text { Conventional } \\
\text { treatment }\end{array}$ & $\begin{array}{l}\text { Attract } \\
\text { \& kill }\end{array}$ & $\begin{array}{c}\text { Conventional } \\
\text { treatment }\end{array}$ & $\begin{array}{l}\text { Attract } \\
\& \text { kill }\end{array}$ & $\begin{array}{c}\text { Conventional } \\
\text { treatment }\end{array}$ \\
\hline Mclntosh & $A$ & 1995 & cypermethrin $^{b}$ & azinphosmethyle & 1.6 & 0.2 & 100.0 & 99.8 \\
\hline Mclntosh & B & 1996 & cypermethrin ${ }^{b}$ & azinphosmethylg ${ }^{9}$ & 2.5 & 2.1 & 92.1 & 97.4 \\
\hline Mclntosh & C & 1997 & cypermethrin ${ }^{b}$ & phosmet $^{\text {h }}$ & 20.3 & 10.1 & 92.4 & 99.1 \\
\hline McIntosh & D & 1996 & cypermethrin ${ }^{c}$ & azinphosmethyl $\left.\right|^{9}$ & 0.5 & 0.6 & 98.9 & 98.6 \\
\hline Mclntosh & $E$ & 1997 & cypermethrin ${ }^{c}$ & phosmet $^{\text {h }}$ & 1.0 & 1.6 & 98.5 & 99.8 \\
\hline Mclntosh & $\mathrm{F}$ & 1998 & deltamethrin ${ }^{d}$ & phosmet & 0.4 & 0.8 & 100.0 & 100.0 \\
\hline Mclntosh & G & 1999 & deltamethrin ${ }^{d}$ & phosmet & 1.3 & 3.8 & 97.0 & 97.9 \\
\hline Liberty & $\mathrm{H}$ & 1995 & cypermethrin ${ }^{b}$ & azinphosmethyl ${ }^{\dagger}$ & 0.4 & 1.0 & 98.8 & 98.2 \\
\hline Liberty & 1 & 1997 & cypermethrin ${ }^{6}$ & phosmet $^{\text {h }}$ & 11.1 & 25.0 & 87.0 & 98.3 \\
\hline Gala & J & 1998 & deltamethrin ${ }^{d}$ & phosmet & 0.5 & 0.1 & 100.0 & 99.6 \\
\hline Jonagold & $\mathrm{J}$ & 1998 & deltamethrim $^{\text {d }}$ & phosmet & 0.5 & 0.1 & 99.9 & 99.6 \\
\hline Gala & K & 1999 & deltamethrin $^{\text {d }}$ & phosmet ${ }^{i}$ & 0.6 & 0.6 & 100.0 & 98.4 \\
\hline Jonagold & K & 1999 & deltamethrin ${ }^{d}$ & phosmet & 0.6 & 0.6 & 98.6 & 98.0 \\
\hline
\end{tabular}

a maximum fly activity was determined by the sum of catches on the four peripheral traps and dividing the sum by eight (the nominal action threhshold).

${ }^{b}$ sprayed with $12.5 \%$ cypermethrin in de-odorized kerosene.

c sprayed with $6.3 \%$ cypermethrin in de-odorized kerosene.

d sprayed with $1.7 \%$ deltamethrin in de-odorized kerosene.

e sprayed with azinphosmethyl (850 $\mathrm{g}$ ai ha-1) on $18 \mathrm{July} 1995$.

f sprayed with azinphosmethyl (850 $\mathrm{g}$ ai ha-1) on $18 \mathrm{July} 1995$ and 3 August 1995.

g sprayed with azinphosmethyl (850 $\mathrm{g}$ ai ha-1) on 16 July 1996.

h sprayed with phosmet $(1.88 \mathrm{~kg}$ ai ha-1) on 11, 30 July and 19 August 1997.

i sprayed with phosmet $(1.88 \mathrm{~kg}$ ai ha-1) on 25 July 1998.

i sprayed with phosmet ( $1.88 \mathrm{~kg}$ ai ha-1) on 17 July 1999. 
by apple trees. These trees were treated except the treatment was applied 17 d after the action threshold for apple maggot had been recorded. Therefore, there was moderate pressure on the experimental plot from the south and east sides. On the west side, the edge of a mixed forest was $200-300$ m away from the plot and we noted several hawthorn trees $300 \mathrm{~m}$ away on the north side. Traps treated with $1.7 \%$ deltamethrin were placed on the first and last row of trees of every column. The columns were $4 \mathrm{~m}$ apart. Traps were also placed on every row of the first and last column. The distance between trees on a row in a column was $4.5 \mathrm{~m}$. A total of 64 traps were used. At harvest, $98.4 \%$ of the 3200 apples examined were injury free and the maximum fly activity was 5.8 times the action threshold.

Based on the results of this pilot study, the "attract and kill" technique was evaluated on four cultivars from 1995 to 1999 inclusive (Table 1). The plots were at the edge of the Agriculture and Agri-Food Canada experimental orchard at Frelighsburg, Quebec. The trials were divided into an experimental plot and a reference check plot of equal size. The reference check plots were treated with the conventional insecticide azinphosmethyl (O,O-dimethyl S-[(4-oxo-1,2,3benzotriazin-3(4H)-yl)-methyl] phosphorodithioate) at $850 \mathrm{~g}$ a.i. ha-1 or phosmet (O,O-dimethyl phosphorodithioate $\mathrm{S}$-ester with $\mathrm{N}$-mercaptomethyl) phthalimide) at $1.88 \mathrm{~kg}$ a.i. $\mathrm{ha}^{-1}$ to manage maggot activity. Meanwhile insecticide treated traps loaded with a synthetic attractant in sachets were used in the experimental plots (Table 1).

The same trees were used from 1995 to 1997 as trials A, B and C (Fig. 2, Tables 1 and 2). The trees were $10 \mathrm{yr}$ old cv. Mclntosh. The experimental plot was $15 \mathrm{~m}$ away from the edge of a deciduous forest on the north side and the same distance from a chemically treated apple plot on the south side. On the east side, the experimental plot was bordered by a wind barrier composed of coniferous trees (10 $\mathrm{m}$ away) and it was congruous with the chemically treated reference check plot on the west side.
Trials $\mathrm{A}, \mathrm{B}$, and $\mathrm{C}$

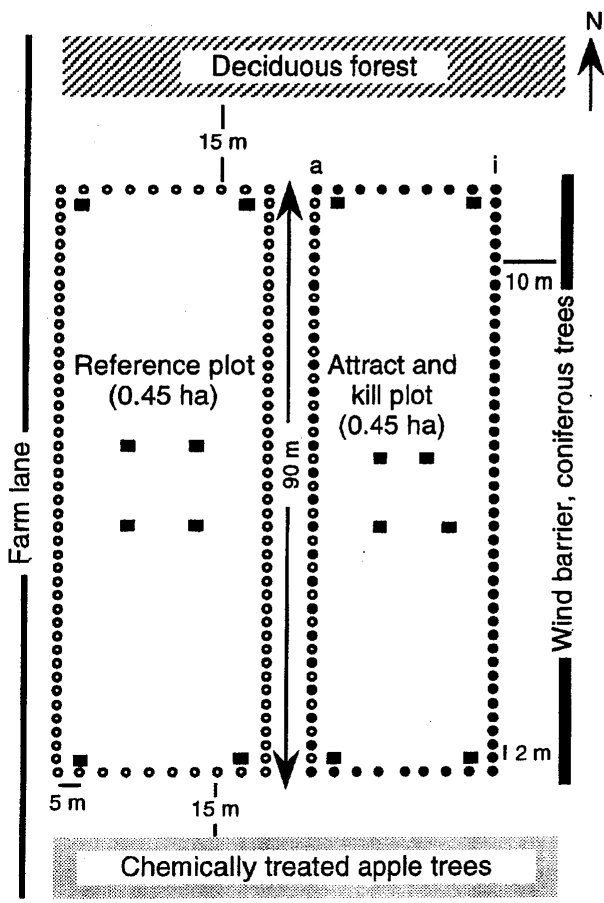

Fig. 2. Trials A, B, and C, Frelighsburg, Quebec, 1995-97. Full dots represent placement of "attract and kill" traps on the periphery of the plot. Traps were placed on the first and last row of trees in every column. The columns were $5 \mathrm{~m}$ apart. Traps were placed at $2 \mathrm{~m}$ intervals in column (i) for all trials. In column (a), traps were placed at $4 \mathrm{~m}$ intervals in trials $A$ and $B(1995-96)$ and at $2 \mathrm{~m}$ intervals in trial $C$ (1997). Full squares represent placement of traps coated with Tangletrap ${ }^{\mathrm{TM}}$. The reference plot was treated once in 1995 and again in 1996 with azinphosmethyl. It was treated three times with phosmet in 1997.

The trials D, E, F, and G (Fig. 3, Tables 1 and 2) were the same trees used from 1996 to 1999 inclusive. Again the trees were $10 \mathrm{yr}$ old and cv. McIntosh. On the south and west sides, the experimental plot faced a mixed forest 15 and $75 \mathrm{~m}$ away. On the east side, it was congruous with the chemically treated reference check plot and on the north side there was another chemically treated plot. 
Trials $D, E, F$, and $G$

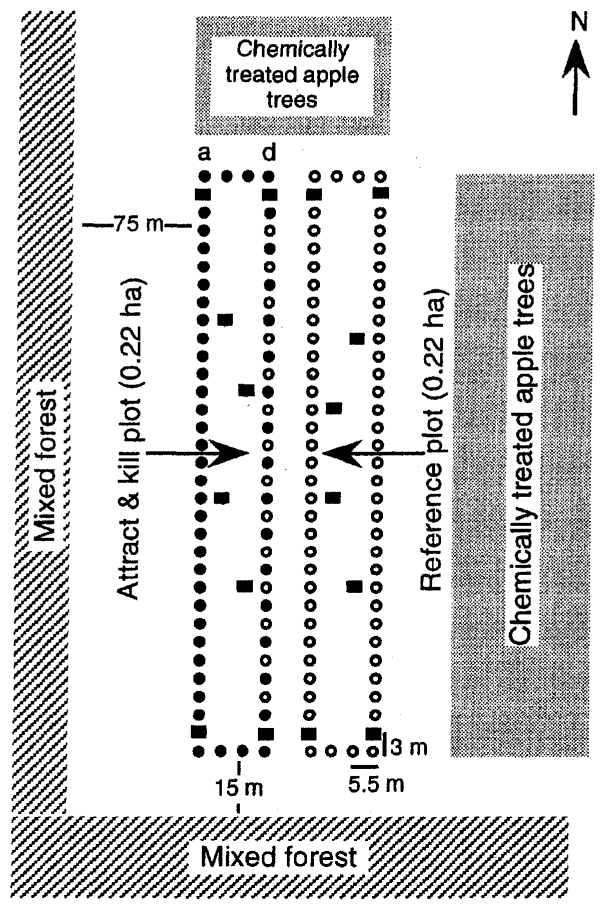

Fig. 3. Trials $D, E, F$, and G, Frelighsburg, Quebec, 1996-99. Full dots represent placement of "attract and kill" traps on the periphery of the plot. Traps were placed on the first and last row of trees in every column. The columns were $5.5 \mathrm{~m}$ apart. Traps were placed at $3 \mathrm{~m}$ intervals in column (a) for the four trials. In column (d), traps were placed at $6 \mathrm{~m}$ intervals in trial $D(1996)$ and at $3 \mathrm{~m}$ intervals in trials $E, F$, and $G$ (1997-99). Full squares represent placement of traps coated with Tangletrap ${ }^{\mathrm{TM}}$. The reference plot was treated once with azinphosmethyl in 1996, three times with phosmet in 1997 and once with phosmet in 1998 and 1999.

The trial $\mathrm{H} \mathrm{cv}$. Liberty was first used in 1995 and again in 1997 as trial I ( Fig. 4, Tables 1 and 2). A deciduous forest was located $120 \mathrm{~m}$ from the north side of the experimental plot whereas the south and west sides were covered with prairie grass. On the east side, it was congruous with the chemically treated reference check plot. Twenty-five m east of the reference check plot was a 0.75 ha untreated apple plot "Entomological zoo" (Fig. 4).

Apple trees comprised of Royal Gala and Jonagold cvs. were first used in 1998 as trial $\mathrm{J}$ and again in 1999 as trial $\mathrm{K}$ (Fig. 5, Tables 1 and 2). On the south and west sides, the experimental plot was opposite a deciduous forest 25 and $80 \mathrm{~m}$ away respectively. On the north side, it was congruous with the chemically treated reference check plot and a farm lane on the east side followed by prairie grass (Fig. 5).

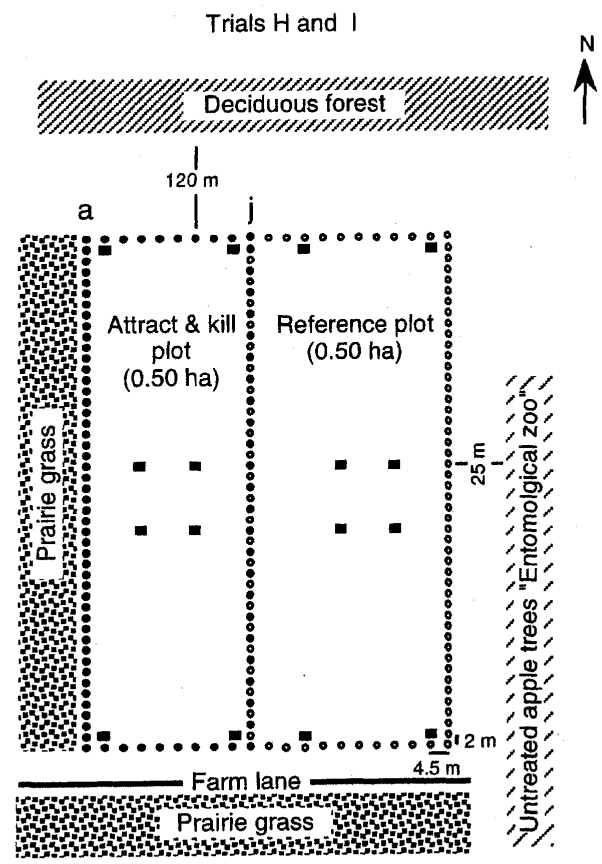

Fig. 4. Trials $H$ and $I$, Frelighsburg, Quebec, 1995 and 1997. Full dots represent placement of "attract and kill" traps on the periphery of the plot. Traps were placed on the first and last row of trees in every column. The columns were $4.5 \mathrm{~m}$ apart. Traps were placed at $2 \mathrm{~m}$ intervals in column (a) for the two trials. In column (j), traps were placed at $4 \mathrm{~m}$ intervals in trial $\mathrm{H}$ (1995) and at $2 \mathrm{~m}$ intervals in trial I (1997). Full squares represent placement of traps coated with Tangletrap ${ }^{\mathrm{TM}}$. The reference plot was treated twice with azinphosmethyl in 1995 and three times with phosmet in 1997. 
Trials $\mathrm{J}$ and $\mathrm{K}$

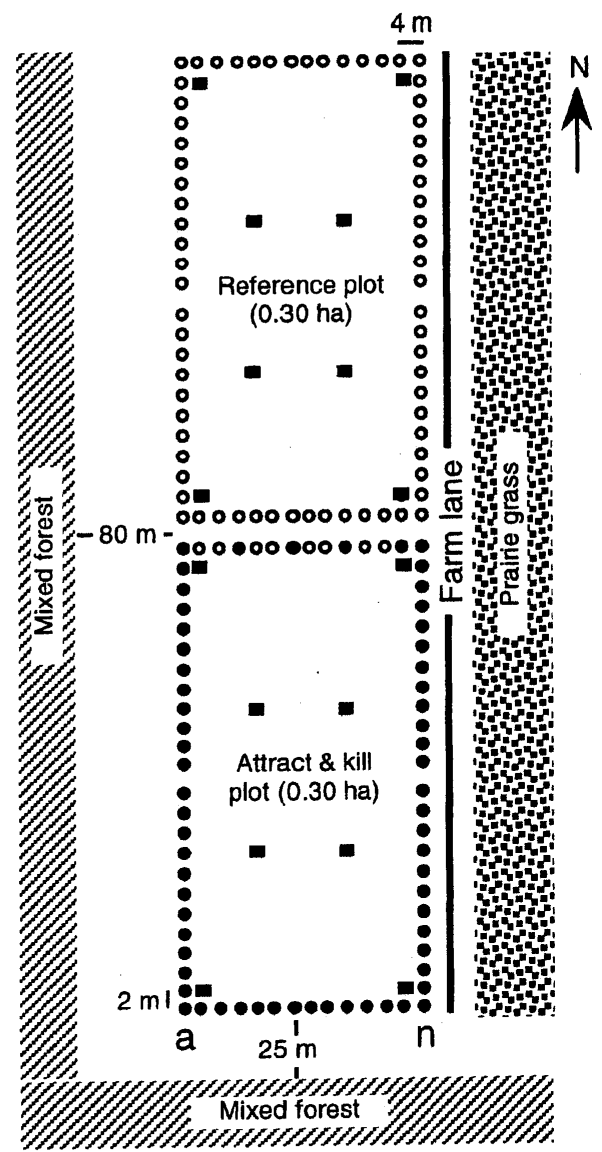

Fig. 5. Trials $\mathrm{J}$ and $\mathrm{K}$, Frelighsburg, Quebec, 1998 and 1999 . Full dots represent placement of "attract and kill" traps on the periphery of the plot. The columns were 4 $\mathrm{m}$ apart. Traps were placed at $2 \mathrm{~m}$ intervals in columns (a) and ( $n$ ) in both trials. On the row opposite the reference plot, traps were placed at $12 \mathrm{~m}$ intervals in both trials. On the row opposite the mixed forest, traps were placed at $4 \mathrm{~m}$ intervals in both trials. Full squares represent placement of traps coated with Tangletrap ${ }^{\mathrm{TM}}$. The reference plot was treated once with phosmet in 1998 and once again in 1999.

Fly catches (four traps) from the interior of each experimental plot for each trial were compared with fly catches from its corresponding chemically treated reference plot. These reference plots could not be strictly considered in the statistical sense as control plots, nevertheless, they were conservative benchmarks for comparison with commercial plots. Based on this premise, each trap was considered as a replicate. The null hypothesis was that the interior of an experimental plot protected by "attract and kill" technique traps should not have more flies than its corresponding chemically treated reference plot.

\section{RESULTS}

Irrespective of cultivar, apple maggot flies were most numerous in 1997 and in the reference check plots of trials $C$ and $I$, three treatments were necessary to manage this pest (Table 1). In the cv. Mclntosh (trial $\mathrm{C}$ ), the maximum activity was 10.1 times the action threshold, and in cv. Liberty (trial I), it was 25 times the action threshold (Table 1). In the remaining $4 \mathrm{yr}$, apple maggot activity appeared to be almost "normal". Normal was defined as a situation whereby commercially acceptable apple maggot control could be secured with a single or at most two conventional insecticide treatments. The vicinity of an untreated apple plot $(25 \mathrm{~m})$ was a constant source of apple maggot in trial H (cv. Liberty) which in turn had to be treated twice in 1995 while trial A in the same yr produced $1.2 \%$ more uninjured fruit with only a single treatment.

The highest maximum fly activity was recorded in the experimental plots of trial B in 1996 and of trials C and I in 1997. Thus, despite a $28 \%$ increase in the number of traps in trial $C$ (Table 2) when compared to trial $B$, apple maggot management for both trials was commercially unacceptable (Table 1). Similarly, an increase of $26 \%$ in trial I when compared to trial $\mathrm{H}$ (Table 2), the level of apple maggot management was again commercially unacceptable (Table 1). In the remaining trials, the traps managed to keep the fly activity under control and the percentage of uninjured fruit was commercially acceptable (Table 1). An unpaired t test comparison showed no significant difference in the number of flies captured in the interior of the experimental plots and the con- 
Table 2. Placement of treated traps to manage apple maggot Rhagoletis pomonella (Walsh) in Quebec apple orchards, 1995-1999

\begin{tabular}{|c|c|c|c|c|c|c|c|c|}
\hline \multirow[b]{2}{*}{ Cultivar } & \multirow[b]{2}{*}{$\begin{array}{c}\text { Trial } \\
\text { designation }\end{array}$} & \multirow[b]{2}{*}{$\begin{array}{l}\text { Number } \\
\text { of traps }\end{array}$} & \multirow[b]{2}{*}{$\begin{array}{l}\text { Distance } \\
(\mathrm{m}) \\
\text { between } \\
\text { column }\end{array}$} & \multirow[b]{2}{*}{$\begin{array}{l}\text { Distance } \\
\text { (m) between } \\
\text { trees in } \\
\text { a column }\end{array}$} & \multicolumn{2}{|c|}{$\begin{array}{l}\text { Number of traps } \\
\mathrm{m}^{-1} \text { in a column }\end{array}$} & \multicolumn{2}{|c|}{$\begin{array}{c}\text { Number of traps } \\
\mathrm{m}^{-1} \text { in a row }\end{array}$} \\
\hline & & & & & $\begin{array}{l}\text { Opposite } \\
\text { a treated } \\
\text { plot }\end{array}$ & $\begin{array}{l}\text { Opposite } \\
\text { a forest }\end{array}$ & $\begin{array}{l}\text { Opposite } \\
\text { a treated } \\
\text { plot }\end{array}$ & $\begin{array}{l}\text { Opposite } \\
\text { a forest }\end{array}$ \\
\hline Mclntosh & $A \& B$ & 80 & 5 & 2 & 0.25 & 0.5 & 0.20 & 0.20 \\
\hline Mclntosh & C & 102 & 5 & 2 & 0.5 & 0.5 & 0.20 & 0.20 \\
\hline Mclntosh & $D$ & 54 & 5.5 & 3 & 0.17 & 0.3 & 0.18 & 0.18 \\
\hline Mclntosh & $E, F, G$ & 70 & 5.5 & 3 & 0.3 & 0.3 & 0.18 & 0.18 \\
\hline Liberty & $\mathrm{H}$ & 89 & 4.5 & 2 & 0.25 & 0.5 & 0.22 & 0.22 \\
\hline Liberty & 1 & 112 & 4.5 & 2 & 0.5 & 0.5 & 0.22 & 0.22 \\
\hline Gala, Jonagold & $J, K$ & 64 & 4 & 2 & 0.5 & 0.5 & 0.08 & 0.25 \\
\hline
\end{tabular}

ventionally treated reference check plots except in trials $\mathrm{F}$ and I (Table 3 ). In trial $F$, the difference was a statistical artifact as there were too few flies per replicate for a meaningful analysis. In trial I, fly activity was too high and the traps failed to control the flies. Only $87 \%$ of the apples were exempt of maggot injury in this experimental plot (Table 1). The maximum fly activity recorded in the experimental plots, which at the same time produced commercially acceptable uninjured 'Mclntosh' apples, was 1.6 times the action threshold (trial $A$ in 1995). When maximum fly activity was beyond 1.6 such as in trials $B, C$, and $I$, the injury level was commercially unacceptable at harvest time (late September to early October depending on the cultivar) (Table 1). The regression equation in Fig. 6 relates maximum fly activity in the experimental plots to percent uninjured fruit at harvest and we note a direct

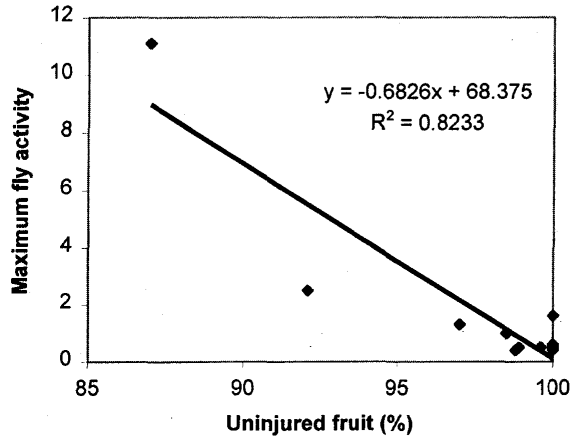

Fig. 6. Relationship (regression equation) of maximum fly activity to percent uninjured fruit at harvest in the "attract and kill" trials. Maximum fly activity was determined by the sum of catches in the four peripheral traps and dividing the sum by eight (the nominal action threshold). Frelighsburg, Quebec, 1995-1999.

Table 3. Annual mean catches of apple maggot Rhagoletis pomonella (Walsh) on the four centre traps for each trial, Frelighsburg, Quebec, 1995 - 1999

\begin{tabular}{lcccccccccccc}
\hline & \multicolumn{11}{c}{ Trial designation } \\
\cline { 2 - 10 } Treatment & $\mathrm{A}$ & $\mathrm{B}$ & $\mathrm{C}$ & $\mathrm{D}$ & $\mathrm{E}$ & $\mathrm{F}$ & $\mathrm{G}$ & $\mathrm{H}$ & $\mathrm{I}$ & $\mathrm{J}$ & $\mathrm{K}$ \\
\hline Conventional & $2.8 \mathrm{a}^{\delta}$ & $5.0 \mathrm{a}$ & $13.0 \mathrm{a}$ & $4.5 \mathrm{a}$ & $5.5 \mathrm{a}$ & $3.5 \mathrm{a}$ & $10.5 \mathrm{a}$ & $2.8 \mathrm{a}$ & $29.3 \mathrm{a}$ & $1.8 \mathrm{a}$ & $9.3 \mathrm{a}$ \\
Attrack and kill & $8.5 \mathrm{a}$ & $14.8 \mathrm{a}$ & $40.5 \mathrm{a}$ & $1.5 \mathrm{a}$ & $5.0 \mathrm{a}$ & $1.5 \mathrm{~b}$ & $9.5 \mathrm{a}$ & $1.3 \mathrm{a}$ & $69.3 \mathrm{~b}$ & $3.0 \mathrm{a}$ & $9.3 \mathrm{a}$ \\
\hline
\end{tabular}

$\delta$ numbers followed by the same letter within a column are not significantly different (unpaired t test, $P<0.05)$. The analysis was performed on $\sqrt{\mathrm{x}+1}$. 


\section{DISCUSSION}

These results indicate that "attract and kill" is an alternative technique to control apple maggot in McIntosh, Liberty, Royal Gala, and Jonagold cv. apples in Quebec.

The traps intercept and kill a large proportion of the females on the perimeter of the plot and allow few to penetrate into the interior of the block. The net result is too few flies in the interior of the plot to cause injuries of economic significance (Table 3). The method was developed with several apple cultivars under the harshest conditions possible: i.e. low to very high apple maggot densities in plots that were near forest habitats. The maximum fly activity that was tolerated, and still resulted in commercially acceptable apple maggot management was 1.6 times the action threshold for that pest. Figure 6 shows that this relationship was linear and it would be possible to predict in advance the quality of the harvest when the maximum fly activity would exceed the action threshold. The "attract and kill " technique could easily be included in an IPM program and when fly activity surpasses this threshold, then the entire block could be treated to reduce the potential of increased injured fruit until harvest. On the side opposite of a treated reference check plot, increasing the number of traps (Table 2) did not increase the percentage of uninjured fruit at harvest (compare percentage of uninjured fruit in trials $A$ and $B$ versus $C$; $D$ versus $E, F, G$; and $H$ versus $I$ ). Using only red spheres, Duan and Prokopy (1995b) reported that a $1.05 \%$ a.i. dimethoate with a feeding stimulant and an unnamed residue-extending agent provided acceptable apple maggot control in Massachusetts as long as the traps were re-treated at least once with the dimethoate and with the sucrose solution after each rainfall. In Tephritidae, the "attract and kill" technique has also been explored and developed in depth to control the olive fruit fly, $\mathrm{Da}$ cus oleae in Greece (Haniotakis et al. 1991).

The disposition of traps depended on the location of the plot in an orchard.
On sides opposite to forests, entry sites of apple maggot into the plot (Bostanian et al. 1999), the distance between adjacent traps in the a column was 2$3 \mathrm{~m}\left(0.3-0.5\right.$ traps $\left.\mathrm{m}^{-1}\right)$. A trap was also placed on every tree of the first and last row of a column. The columns were 4-

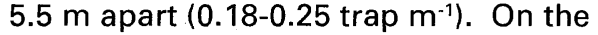
other hand, opposite to prairie grass or conventionally chemically treated apple plot fewer traps were sometimes used. The distance between adjacent traps in a column was 2-6 m (0.17-0.5 traps $\left.\mathrm{m}^{-1}\right)$. On the row, the distance between adjacent traps was 4-12 m (0.08-0.25 traps $\mathrm{m}^{-1}$ ). The traps were always hung on outer branches 1.20 to $1.70 \mathrm{~m}$ above the ground and positioned to be fully visible from outside the tree canopy.

Similar to perimeter trapping (Bostanian et al. 1999), the number of attractant loaded traps per plot was a function of the length of the plot opposite a possible entry site of apple maggot. Three to five times more such traps were used in a column facing a possible entry site in the "attract and kill" trials than in perimeter trapping (Bostanian et al. 1999). However, insecticide treated traps used in the "attract and kill" technique were easier to handle and, once installed, maintenance free. In contrast, with perimeter trapping, coating traps with Tangletrap ${ }^{\mathrm{Tm}}$ (Tanglefoot Co., Grand Rapids Michigan) on a commercial scale was awkward and labor intensive. Furthermore, the sticky traps had to be cleaned and re-coated or replaced at intervals of 2-3 wk (Bostanian et al. 1999).

As noted earlier, apple maggot activity appears to be less intense in Quebec (Bostanian et al. 1984). Consequently, the "attract and kill" technique may be an attractive alternative to conventional insecticide treatments to manage this pest. This is more pronounced, as the results of this study indicate that a single set of "attract and kill" traps provided adequate control of apple maggot for the entire season as long as the maximum fly activity did not exceed 1.6 times the action threshold for this pest (Fig. 6). No effort was made in our study to cut down possible sources of 
R. pomonella from wild or neglected Rosaceae. This was based on Maxwell (1968) who reported that apple maggot females move several hundred $m$ while foraging for hosts. Therefore, cutting down nearby few unmanaged host trees would likely have little impact on apple maggot activity. However, the technique is doomed to fail in the vicinity of a totally neglected orchard.

Finally, it is worth mentioning that similar to perimeter trapping (Bostanian et al. 1999), the orchard should initially be free of apple maggot populations and therefore most if not all apple maggot injuries should be caused by flies coming from adjacent habitat. With an infested plot, it is suggested that a chemical control program be used along with the collection of all infested apples on the ground, before the larvae leave the apples and enter the soil to hibernate, for one to two seasons before implementing the "attract and kill" technique.

Since the use of an insecticide is limited to the treated traps, there should be no adverse effects non-target species. Such an approach would allow beneficial species to attain maximum abundance and exert their effect on pest populations.

\section{ACKNOWLEDGMENTS}

The authors extend their gratitude to Aventis Crop Sciences and Zeneca Agro for supplying the two insecticides, and to B. Rancourt of the Horticultural Research and Development Centre for Fig.1. This is Contribution no. 335/ 2001.04.01R of Horticultural Research \& Development Centre, Agriculture and Agri-Food Canada, Saint-Jean-sur-Richelieu, Quebec, Canada.

\section{REFERENCES}

Bostanian, N.J., C.D. Dondale, M.R. Binns, and D. Pitre. 1984. Effects of pesticide use on spiders (Araneae) in Quebec apple orchards. Can. Entomol. 116 : 663675.

Bostanian, N.J., C. Vincent, G. Chouinard, and G. Racette 1999. Managing apple maggot, Rhagoletis pomonella [Diptera : Tephritidae] by perimeter trapping. Phytoprotection $80: 21-33$.

Duan, J.J., and R.J. Prokopy. 1995a. Control of apple maggot flies (Diptera : Tephritidae) with pesticide-treated red spheres. J. Econ. Entomol. 88 : 700-707.

Duan, J.J., and R.J. Prokopy. 1995b. Development of pesticide-treated spheres for controlling apple maggot flies (Diptera : Tephritidae) : pesticides and residue extending agents. J. Econ. Entomol. 88 : 117-126.

Fein, B.L., W.H. Reissig, and W.L. Roelofs. 1982. Identification of apple volatiles attractive to the apple maggot, Rhagoletis pomonella. J. Chem. Ecol. 8 : 1473-1487.

Haniotakis, G., M. Kozyrakis, T. Fitsakis, and A. Antonidaki. 1991. An effective mass trapping method for the control of Dacus oleae (Diptera : Tephritidae). J. Econ. Entomol. 84 : 564-569.

Kring, J.B. 1970. Red spheres and yellow panels combined to attract apple maggot flies. J. Econ. Entomol. 63 : 466-469.

Mason. J., R.J. Prokopy, S. Wright, S. Goodall, K. Jones, Y. Ma, V. Mohr, and M. Nogaki. 1994. Apple integrated pest management in 1993 : Insects and mites in second-level orchard blocks. Fruit Notes $59: 1-7$.

Maxwell, C.W. 1968 . The recapture of marked apple maggot adults in several orchards from one release point. J. Econ. Entomol. 61: 1157-1159.

Prokopy, R.J. 1968. Visual responses of apple maggot flies Rhagoletis pomonella : orchard studies. Entomol. Exp. Appl. $11: 403-422$.

Prokopy, R.J. 1975. Apple maggot control by sticky spheres. J. Econ. Entomol. 68 : 197-198.

Prokopy, R.J., S.A. Johnson, and M.T. O'Brien. 1990. Second-stage integrated management of apple arthropod pests. Entomol. Exp. Appl. 54 : 9-19.

Reissig, W.H., B.H. Stanley, W.L. Roelofs, and M.R. Schwarz. 1985. Tests of synthetic apple volatiles in traps as attractants for apple maggot flies (Diptera: Tephritidae) in commercial apple orchards. Environ. Entomol. 14 : 55-59.

Trimble, R.M., and P.M. Vickers. 2000. Evaluation of border sprays for managing the codling moth (Tortricidae : Lepidoptera) and the apple maggot (Tephritidae : Diptera) in Ontario apple orchards. J. Econ. Entomol. 93 : 777-787.

Vincent, C., and N.J. Bostanian. 1988. La protection des vergers de pommiers au Québec : état de la question. Nat. Can. (Que.) $115:$ 261-276. 